\title{
Zooplankton community in the Upper Parnaíba River (Northeastern, Brazil)
}

\author{
P. H. S. Picapedra ${ }^{a *}$, C. Fernandes ${ }^{b}$ and F. A. Lansac-Tôha ${ }^{a, c}$ \\ aPrograma de Pós-graduação em Biologia Comparada, Universidade Estadual de Maringá - UEM, \\ Avenida Colombo, 5790, CEP 87020-900, Maringá, PR, Brazil \\ ${ }^{\mathrm{b}}$ Grupo de Pesquisas em Recursos Pesqueiros e Limnologia, Universidade Estadual do Oeste do Paraná - UNIOESTE, \\ Rua da Faculdade, 645, CEP 85903-000, Toledo, PR, Brazil \\ ${ }^{\mathrm{c}}$ Núcleo de Pesquisas em Limnologia Ictiologia e Aquicultura, Programa de Pós-graduação em Ecologia de Ambientes \\ Aquáticos Continentais, Universidade Estadual de Maringá - UEM, Avenida Colombo, 5790, CEP 87020-900, \\ Maringá, PR, Brazil \\ *e-mail: pablo_picapedra@hotmail.com
}

Received: November 26, 2015 - Accepted: February 3, 2016 - Distributed: May 31, 2017

(With 3 figures)

\begin{abstract}
The objective of the present work is to evaluate the seasonal patterns of species richness and abundance of the zooplankton community in a semi-arid river, Northeastern of Brazil. Zooplankton samples were taken in four hydrological periods along the Upper Parnaíba River: April (low), August (dry), November (rising) 2013 and January (flood) 2014. The zooplankton community consisted of 125 species; the testate amoebae was the most species-rich (56 species) and the most abundant group (71.5\%) of total zooplankton abundance. Season-specific differences were highly significant. The overall zooplankton richness and abundance was significantly higher during the low (71 species) and flood (878.47 ind. $\mathrm{m}^{-3}$ ) period, respectively. The hydrological regime was important in structuring the zooplankton community, emphasising the importance of the Parnaíba River and its seasonal variation for biodiversity conservation in the Brazilian semi-arid region.
\end{abstract}

Keywords: potamoplankton, large rivers, semi-arid, environmental variables, seasonality.

\section{Comunidade zooplanctônica do alto rio Parnaíba (Nordeste, Brasil)}

\section{Resumo}

O objetivo deste trabalho foi avaliar os padrões sazonais da riqueza de espécies e abundância da comunidade zooplanctônica em um rio do semi-árido, Nordeste do Brasil. As amostragens do zooplâncton foram realizadas em quatro períodos hidrológicos ao longo do alto rio Parnaíba: Abril (vazante), Agosto (seca), Novembro (enchente) de 2013 e Janeiro (cheia) de 2014. A comunidade zooplanctônica foi constituída por 125 espécies, sendo as amebas testáceas o grupo mais rico em espécies (56 espécies) e o grupo mais abundante (71,5\%) do zooplâncton. Diferenças significativas foram registradas entre os períodos. A riqueza e a abundância do zooplâncton foram significativamente maiores durante o período de vazante (71 espécies) e cheia $\left(878,47\right.$ ind. $\left.\mathrm{m}^{-3}\right)$, respectivamente. Os resultados mostraram ainda, que o regime hidrológico foi importante na estruturação da comunidade zooplanctônica, ressaltando a importância do rio Parnaíba e sua variação sazonal para a conservação da biodiversidade do semi-árido brasileiro.

Palavras-chave: potamoplâncton, grandes rios, semi-árido, variáveis ambientais, sazonalidade.

\section{Introduction}

The Parnaíba River and its tributaries form one of major river systems in northeastern Brazil, crossing the semi-arid region that includes the biomes Caatinga and Cerrado (Medeiros et al., 2011). The Brazilian semi-arid region is characterised by the predominance of intermittent rivers and streams, complex weather patterns, scarce rainfall unevenly distributed and low thermal amplitude (Maltchik and Medeiros, 2006; Medeiros et al., 2011).

As a result, many of the tributaries of the Parnaíba River have characteristics ranging from extreme flooding to the total absence of water, which contributes to a high degree of spatial variation and habitat heterogeneity (Medeiros et al., 2011).

Studies on zooplankton ecology are underscored in lentic environments, while few studies have demonstrated the ecological importance of zooplankton in fluvial environments 
(Perbiche-Neves et al., 2012). In the northeastern Brazil, studies on the potamoplankton are scarce, highlighting recent work by Medeiros et al. (2011) and Lucena et al. (2015), although zooplankton studies in lentic environments are not uncommon to the region (e.g., Eskinazi-Sant'Anna et al., 2007; Almeida et al., 2009; Paranhos et al., 2013). The lack of extensive studies on the ecological processes of the Caatinga biome and its water courses, as well as the lack of knowledge about its biodiversity, has led to the incorrect perception that its aquatic biota is poor in species and endemism. Not surprisingly, most of the studies in aquatic systems of the semi-arid region of Brazil were concentrated in artificial lakes from dammed intermittent streams and rivers (Maltchik and Medeiros, 2006).

Rivers of the Brazilian semi-arid are important economically (e.g., as a source of water and fish), culturally, scientifically, environmentally (e.g., as part of the global hydrological cycle) and for conservation (regional biodiversity and endemic hotspots). The most important issues in the conservation of the semi-arid rivers are the need for recognition of important areas to maintain biodiversity and that this biodiversity is closely associated with the natural patterns of flow and hydrological alterations (Maltchik and Medeiros, 2006). Without an understanding of how the extremes of flood and drought affect aquatic fauna, strategies for the conservation of rivers in the Brazilian semi-arid and their biota will not be effective (Maltchik and Medeiros, 2006; Lucena et al., 2015).

In this way, this study aimed to evaluate the seasonal patterns of species richness and abundance of the zooplankton community in the Parnaíba River. We predicted that: (i) the highest species richness coincides with the flood period, indicating an intensive exchange of fauna during this period, given the greater connectivity between environments and (ii) the higher zooplankton abundance coincides with the dry period, indicating no dilution effect during this period, caused by a lower connectivity between environments.

\section{Material and Methods}

\subsection{Study site}

The Parnaíba River is on the border between the states of Maranhão and Piauí, Northeastern of Brazil (Figure 1). It is 1,432 kilometres long and drains an area of about $344,112 \mathrm{~km}^{2}$. It is located in a transition area between semi-arid $(B S h)$ and tropical $(A w)$ climates (Peel et al., 2007). Most tributaries in the middle and lower portions of the river are perennial, while the small rivers and streams in the upper region are intermittent (Rosa et al., 2003; EPE, 2005). Rainfall in the area ranges from 600 to $1,800 \mathrm{~mm}$ per year, and the temperature varies between $24-38{ }^{\circ} \mathrm{C}$ (CODEVASF, 2010).

The Parnaíba River is divided into upper, middle and lower portions; the upper portion is characterised by steep slopes and deeper valleys, the middle portion has uneven terrain with some waterfalls and the lower portion shows a more gradual slope and wider valleys (EPE, 2005; Brasil, 2006). The vegetation cover in the basin is diverse, from dense to sparse vegetation types associated with the Caatinga and the Cerrado (CODEVASF, 2010).

\subsection{Sampling}

Zooplankton samplings were conducted in four quarterly collections: April (low), August (dry), November (rising) 2013 and January (flood) 2014. We sampled seven sites in the channel of the Parnaíba River and also a site at the mouth of each tributary, three on the left bank and two on the right bank of the river, totalling 12 sampling sites (Figure 1).

Zooplankton samples were taken with a suction pump filter 600 liters of water per sample through a conical plankton net of $60 \mu \mathrm{m}$ mesh size. The collected material was placed in a polyethylene bottle $(500 \mathrm{~mL})$ properly labelled and fixed in 4\% formaldehyde solution buffered with sodium borate $\left(\mathrm{Na}_{3} \mathrm{BO}_{3}\right)$.

Concurrently with the zooplankton sampling, environmental variables were collected (water temperature, dissolved oxygen, $\mathrm{pH}$, electrical conductivity and turbidity) using portable digital devices. Water samples were also taken in containers of 5 liters and subsequently sent to the laboratory of Grupo de Pesquisas em Recursos Pesqueiros e Limnologia (GERPEL) for chlorophyll- $a$ analysis (Golterman et al., 1978). Water level data were provided by the Agência Nacional de Águas (ANA). The water velocity was measured using the mechanic flowmeter (Flowmeter Gereral Oceanics $^{\mathrm{TM}}$ ).

\subsection{Analysis of community data}

The zooplankton samples were counted in an optical microscope (Olympus), using a Sedgewick-Rafter chamber. Samples were concentrated to $100 \mathrm{~mL}$, and $50 \mathrm{~mL}$ were taken with Hensen-Stempel pipettes. The zooplankton community was analysed for species richness and abundance. The total abundance was expressed in terms of individuals per $\mathrm{m}^{-3}$. The individuals were identified using specialized taxonomic literature (Koste, 1978; Vucetich, 1973; Reid, 1985; Matsumura-Tundisi, 1986; Segers, 1995; Velho and Lansac-Tôha, 1996; Velho et al., 1996; Elmoor-Loureiro, 1997; Lansac-Tôha et al., 2002).

\subsection{Statistical analysis}

The non-parametric analysis of variance (Kruskal-Wallis test) (Zar, 1999) was used to assess the seasonal differences in species richness and abundance of the zooplankton community. The Bray-Curtis similarity coefficient was calculated, aiming to quantify the differences in abundance between the hydrological periods. This coefficient calculates the absolute differences and the sums of the abundances of species in the samples; it is strongly influenced by the dominant species and does not consider double-absences. The closer the samples are, the smaller the distance between them, and, therefore, the greater the similarity between them (Valentin, 2000). The abundance of the zooplankton community species was correlated with the environmental variables using a canonical correspondence analysis (CCA). This analysis seeks the largest linear combinations 


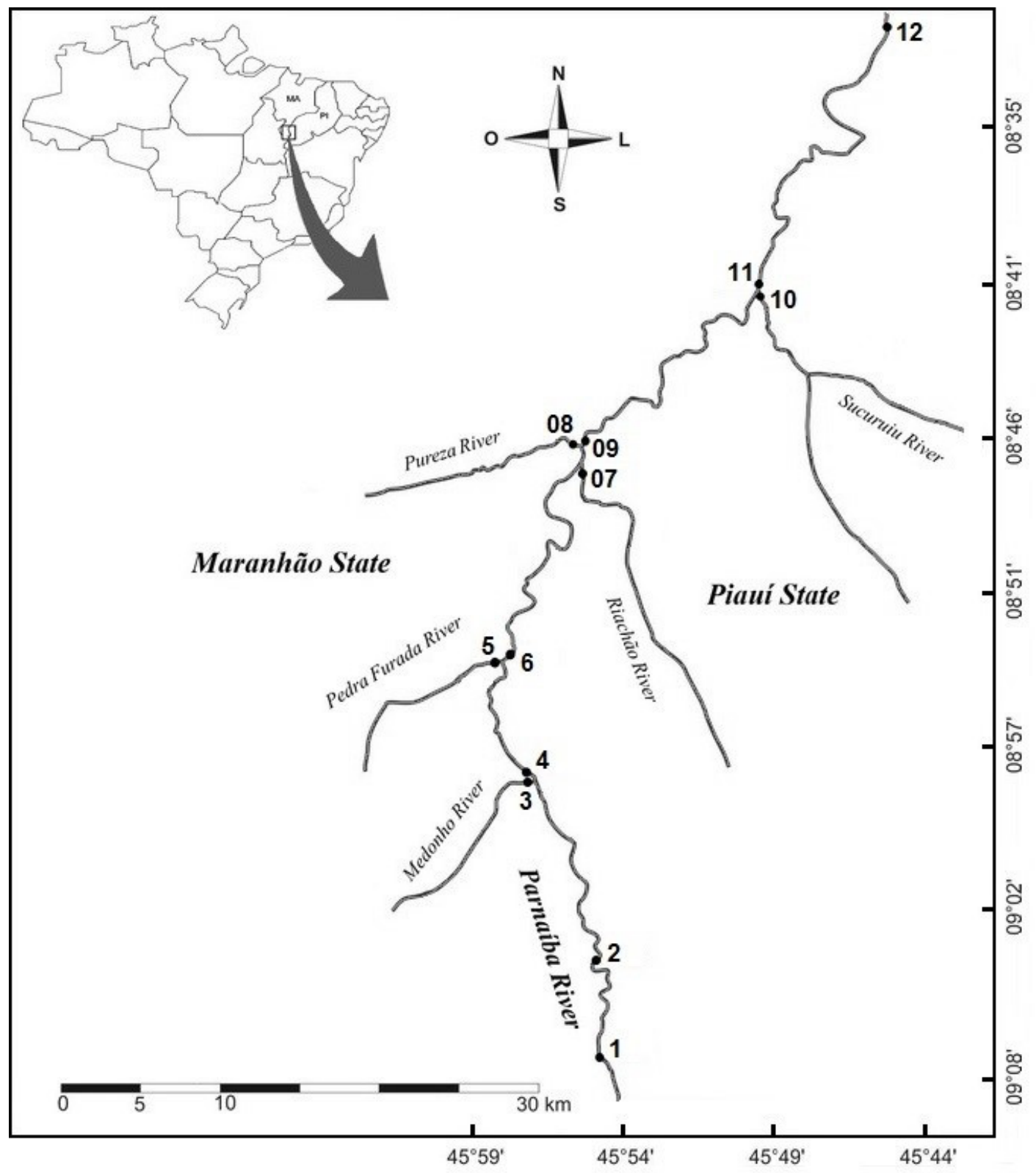

Figure 1. Location of sampling sites in the region of the Upper Parnaíba River, Northeastern Brazil.

between two data sets and enables a simplified view in a two-dimensional plot (Manly, 2008).

The Kruskal-Wallis test, cluster analysis with Bray-Curtis coefficient and CCA were run using the software PC-ORD ${ }^{\circledR}$ (McCune and Mefford 1997).

\section{Results}

The river level showed the highest value in flood and lowest in dry period. The increase in the velocity of water was positively correlated with the increase in the river level. The environmental variables $\mathrm{pH}$, electrical conductivity, temperature, turbidity, dissolved oxygen and chlorophyll- $a$ were higher in periods of flood and low water conditions, while the lowest values were recorded in the dry period (Table 1).

The zooplankton community was represented by 125 species; the testate amoebae had the highest species richness (56 species), followed by rotifers ( 52 species), cladocerans (15 species) and copepods (two species). Testate amoebae were represented by 10 families; the greatest richness was observed for Difflugiidae (20 species) and Arcellidae (11 species). Rotifers were distributed in 14 families, of which Brachionidae (11 species) and Lecanidae (10 species) were the most species-rich. Among microcrustaceans, cladocerans were represented by six families; Chydoridae (eight species) showed the highest 
species richness, and copepods were represented by two species of the family Cyclopidae (Table 2).

In the different hydrological periods, the highest number of species (71 species) was registered in the low period, followed by periods of dry ( 69 species), rising ( 67 species) and flood (60 species). Testate amoebae showed higher species richness during the flood period ( 38 species), and was the most species-rich group in all studied periods, except in the low period, when the number of species was similar to that of rotifers. Rotifers presented the highest species richness during the dry period (32 species). Among microcrustaceans, cladocerans showed higher richness in the low and rising periods (eight species) and copepods during the flood period (two species) (Figure 2a). The variation in the mean richness values was driven by the expressive contribution of testate amoebae and rotifers (Figure 2b).

Table 1. Mean ( \pm SE) of environmental variables measured in the Parnaíba River (Northeastern Brazil) in low, dry, rising and flood periods.

\begin{tabular}{lcccc}
\hline \multicolumn{1}{c}{ Parnaíba River } & & \\
\hline \multicolumn{1}{c}{ Environmental variables } & Low & Dry & Rising & Flood \\
\hline Fluviometric level $(\mathrm{cm})$ & $380 \pm 39.83$ & $327 \pm 2.5$ & $371 \pm 79.6$ & $398 \pm 66.3$ \\
Water velocity $(\mathrm{m} / \mathrm{s})$ & $0.95 \pm 0.06$ & $0.69 \pm 0.07$ & $0.73 \pm 0.06$ & $0.83 \pm 0.05$ \\
$\mathrm{pH}$ & $6.24 \pm 0.1$ & $5.45 \pm 0.04$ & $5.82 \pm 0.09$ & $6.47 \pm 0.2$ \\
Electrical conductivity $\left(\mu \mathrm{S} / \mathrm{cm}^{-1}\right)$ & $9.98 \pm 0.85$ & $5.25 \pm 0.42$ & $6.43 \pm 0.69$ & $9.85 \pm 1.42$ \\
Temperature $\left({ }^{\circ} \mathrm{C}\right)$ & $26.7 \pm 0.25$ & $24.4 \pm 0.26$ & $25.2 \pm 0.18$ & $27.8 \pm 0.44$ \\
Turbidity $(\mathrm{NTU})$ & $75.97 \pm 19.68$ & $6.6 \pm 0.76$ & $34.22 \pm 10.07$ & $49.93 \pm 14.82$ \\
Dissolved oxygen $\left(\mathrm{mg} / \mathrm{L}^{-1}\right)$ & $7.53 \pm 0.11$ & $6.89 \pm 0.16$ & $7.18 \pm 0.16$ & $7.26 \pm 0.07$ \\
Chlorophyll- $a\left(\mu \mathrm{g} / \mathrm{L}^{-1}\right)$ & $0.32 \pm 0.15$ & $0.11 \pm 0.07$ & $0.37 \pm 0.13$ & $3.56 \pm 1.7$ \\
\hline
\end{tabular}

(a)
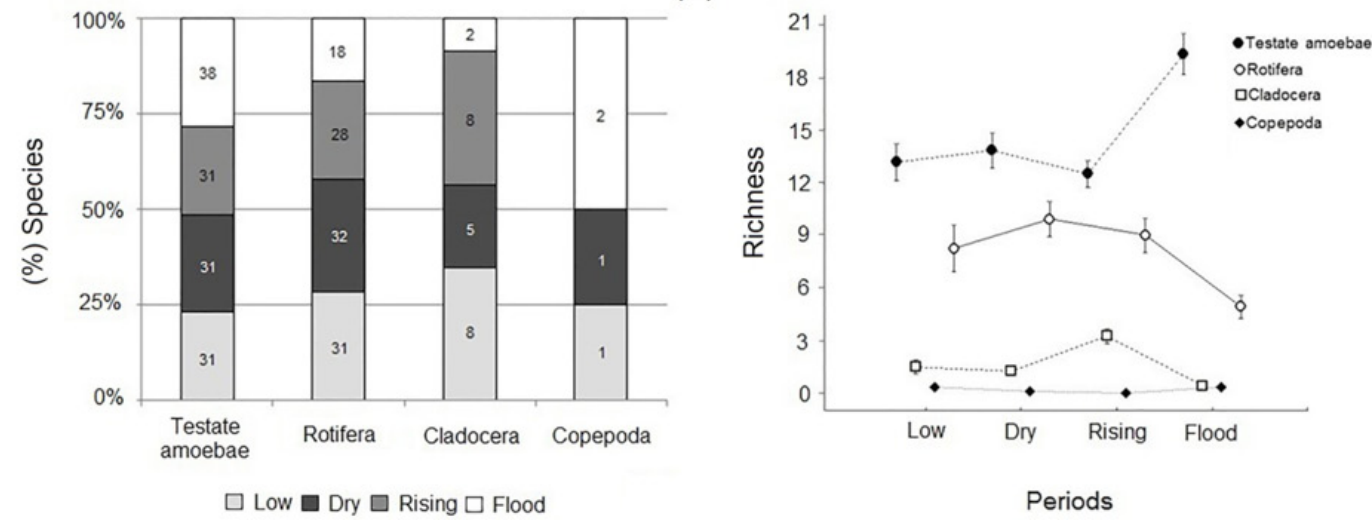

(c)
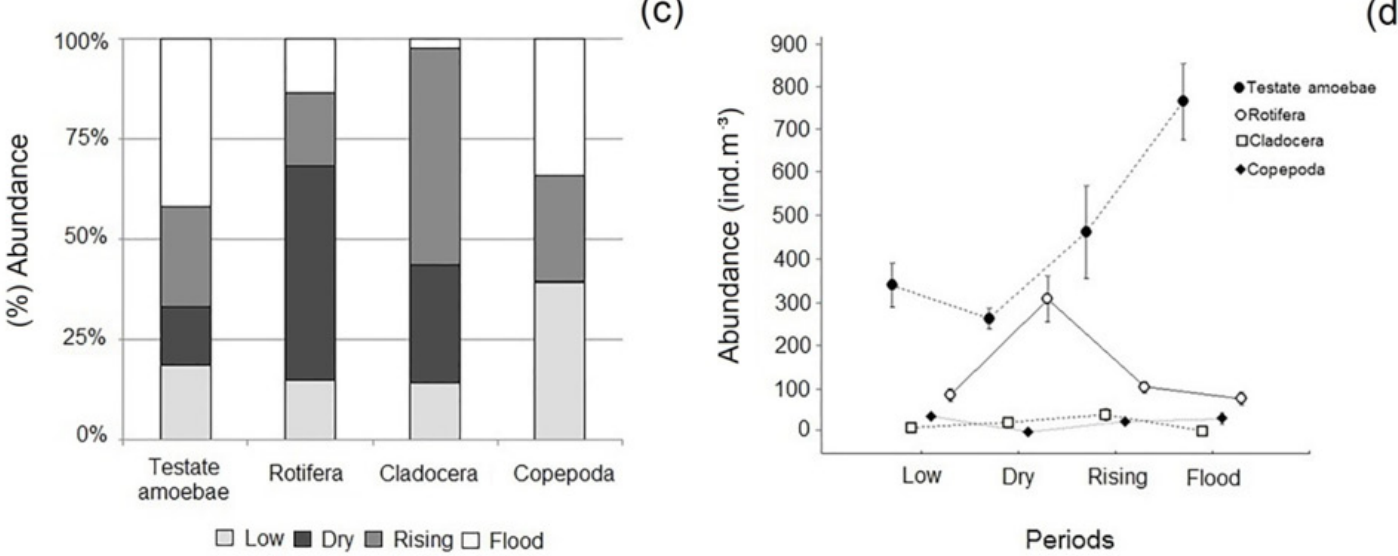

(d)

Figure 2. (a) Number of species (\%); (b) mean species richness ( \pm SE); (c) abundance (\%) and (d) mean abundance ( \pm SE) of Testate amoebae, Rotifera, Cladocera and Copepoda during low, dry, rising and flood periods in the Parnaíba River, Northeastern Brazil. 
Table 2. List of zooplankton taxa recorded in the Parnaíba River (Northeastern Brazil).

\section{Testate Amoebae}

\section{ARCELLIDAE}

Arcella brasiliensis Cunha, 1913

A. conica (Playfair, 1918)

A. costata Ehrenberg, 1847

A. crenulata Deflandre, 1928

A. dentata Ehrenberg, 1830

A. discoides Ehrenberg, 1843

\begin{tabular}{ll}
\hline & CENTROPYXIDAE \\
Centropyxis aculeata $($ Ehrenberg, 1838) & C. gibba (Deflandre, 1929) \\
C. cassis (Wallich, 1864) & C. marsupiformis Deflandre, 1929 \\
C. discoides Pénard, 1902 & Centropyxis sp.
\end{tabular}

A. gibbosa Pénard, 1890

A. hemisphaerica gibba Deflandre, 1928

A. megastoma Pénard, 1902

A. rotundata Playfair, 1918

A. vulgaris Ehrenberg, 1830

C. ecornis (Ehrenberg, 1841)

\section{CYPHODERIIDAE}

Cyphoderia ampulla (Ehrenberg, 1840)

\section{DIFFLUGIIDAE}

Cucurbitella dentata quinquelobata Gauthier-Lièvre and $\quad$ D. litophila Pénard, 1902

Thomas, 1960

Difflugia acuminata Ehrenberg, 1838

D. lobostoma Leidy, 1879

D. compressa (Carter, 1864)

D. minuta Rampi, 1950

D. constricta Ehrenberg, 1841

D. oblonga Ehrenberg, 1838

D. corona Wallich, 1864

D. penardi Hopkinson, 1909

D. cylindrus (Thomas, 1953)

D. pseudogramen Gauthier-Lièvre and Thomas, 1960

D. distenda (Pénard, 1899)

D. pyriformis Perty, 1849

D. elegans Pénard, 1890

Difflugia sp.

D. gramen Pénard, 1902

D. urceolata Carter, 1864

D. linearis Gauthier and Lièvre, 1958

D. cf. yorkui Nicholls, 2007

Euglypha acanthophora (Ehrenberg, 1841)

E. denticulata Brown, 1912

E. filifera Pénard, 1890

E. laevis (Perty, 1849)

Euglypha sp.

HYALOSPHENIIDAE

Heleopera sp.

H. papilio Leidy, 1874

Hyalosphenia cuneata Stein, 1857

Lesquereusia spiralis (Ehrenberg, 1840)

\section{LESQUEREUSIDAE}

Netzelia oviformis (Cash, 1909)

Lesquereusia sp.

\section{PARAQUADRULIDAE}

Quadrulella symmetrica tubulata (Gauthier-Lievre, 1953)

\begin{tabular}{lc} 
& TRIGONOPYXIDAE \\
Cyclopyxis impressa (Daday, 1905) & Cyclopyxis sp. \\
C. kahli (Deflandre, 1929) & \\
\hline & TRINEMATIIDAE \\
Trinema enchelys (Ehrenberg, 1838) & T. lineare Pénard, 1890 \\
\hline
\end{tabular}


Table 2. Continued...

\begin{tabular}{|c|c|}
\hline \multicolumn{2}{|c|}{ Rotifera } \\
\hline \multicolumn{2}{|c|}{ BRACHIONIDAE } \\
\hline Brachionus calyciflorus Pallas, 1766 & K. cochlearis (Gosse, 1851) \\
\hline B. caudatus Barrois and Dadai, 1894 & K. lenzi Hauer, 1953 \\
\hline B. dolabratus Harring, 1914 & K. tropica (Apstein, 1907) \\
\hline B. falcatus Zacharias, 1898 & Plationus patulus (Müller, 1786) \\
\hline Kellicottia bostoniensis (Rousselet, 1908) & Platyias quadricornis (Ehrenberg, 1832) \\
\hline \multicolumn{2}{|l|}{ Keratella americana Carlin, 1943} \\
\hline \multicolumn{2}{|c|}{ COLLOTHECIDAE } \\
\hline \multicolumn{2}{|l|}{ Collotheca sp. } \\
\hline \multicolumn{2}{|c|}{ CONOCHILIDAE } \\
\hline \multicolumn{2}{|l|}{ Conochilus coenobasis (Skorikow, 1914) } \\
\hline \multicolumn{2}{|c|}{ EUCHLANIDAE } \\
\hline Dipleuchlanis propatula (Gosse, 1886) & Euchlanis dilatata Ehrenberg, 1832 \\
\hline \multicolumn{2}{|c|}{ HEXARTHRIDAE } \\
\hline \multicolumn{2}{|l|}{ Hexarthra sp. } \\
\hline \multicolumn{2}{|c|}{ LECANIDAE } \\
\hline Lecane bulla (Gosse, 1851) & L. lunaris (Ehrenberg, 1832) \\
\hline L. cornuta (Müller, 1786) & L. proiecta Hauer, 1956 \\
\hline L. leontina (Turner, 1892) & L. quadridentata (Ehrenberg, 1830) \\
\hline L. ludwigi (Eckstein, 1883) & L. signifera (Jennings, 1896) \\
\hline L. luna (Müller, 1776) & Lecane sp. \\
\hline \multicolumn{2}{|c|}{ LEPADELLIDAE } \\
\hline Lepadella cristata (Rousselet, 1893) & Lepadella sp. \\
\hline L. ovalis (Müller, 1786) & Paracolurella logima (Myers, 1934) \\
\hline L. patella (Müller, 1773) & \\
\hline \multicolumn{2}{|c|}{ NOTOMMATIDAE } \\
\hline Cephalodella gibba (Ehrenberg, 1830) & Notommata copeus Ehrenberg, 1834 \\
\hline Cephalodella sp. & Monommata sp. \\
\hline \multicolumn{2}{|c|}{ PHILODINIDAE } \\
\hline Dissotrocha aculeata (Ehrenberg, 1832) & Dissotrocha sp. \\
\hline \multicolumn{2}{|c|}{ SYNCHAETIDAE } \\
\hline Ploesoma hudsoni (Imhof, 1891) & Polyarthra dolichoptera Idelson, 1925 \\
\hline Synchaeta stylata Wierzejski, 1893 & P. vulgaris (Carlin, 1943) \\
\hline \multicolumn{2}{|c|}{ TESTUDINELLIDAE } \\
\hline Testudinella patina (Hermann, 1783) & T. tridentata Smirnov, 1931 \\
\hline \multicolumn{2}{|c|}{ TRICHOCERCIDAE } \\
\hline Trichocerca bicristata (Gosse, 1887) & T. similis (Wierzejski, 1893) \\
\hline T. cylindrica (Imhof, 1891) & Trichocerca sp. \\
\hline \multicolumn{2}{|c|}{ TRICHOTRIIDAE } \\
\hline Macrochaetus sericus (Thorpe, 1893) & Trichotria tetractis (Ehrenberg, 1830) \\
\hline \multicolumn{2}{|l|}{ M. collinsii (Gosse, 1867) } \\
\hline \multicolumn{2}{|c|}{ TROCHOSPHAERIDAE } \\
\hline Filinia opoliensis (Zacharias, 1898) & F. terminalis (Plate, 1886) \\
\hline
\end{tabular}


Table 2. Continued...

\begin{tabular}{|c|c|}
\hline \multicolumn{2}{|c|}{ Cladocera } \\
\hline \multicolumn{2}{|c|}{ BOSMINIDAE } \\
\hline Bosmina hagmanni Stingelin, 1904 & Bosmina sp. \\
\hline \multicolumn{2}{|c|}{ CHYDORIDAE } \\
\hline Acroperus tupinamba Sinev and Elmoor-Loureiro, 2010 & Chydorus eurynotus Sars, 1901 \\
\hline Alona dentifera (Sars, 1901) & Chydorus sp. \\
\hline A. glabra Sars, 1901 & Coronatella poppei (Richard, 1897) \\
\hline Alonella dadayi Birge, 1910 & Picripleuroxus cf. denticulatus (Elmoor-Loureiro, 1997) \\
\hline \multicolumn{2}{|c|}{ DAPHNIIDAE } \\
\hline Ceriodaphnia cornuta Sars, 1886 & Daphnia gessneri Herbst, 1967 \\
\hline \multicolumn{2}{|c|}{ ILYOCRYPTIDAE } \\
\hline \multicolumn{2}{|l|}{ Ilyocryptus spinifer Herrick, 1882} \\
\hline \multicolumn{2}{|c|}{ MACROTHRICIDAE } \\
\hline \multicolumn{2}{|l|}{ Macrothrix laticornis (Jurine, 1820) } \\
\hline \multicolumn{2}{|c|}{ SIDIDAE } \\
\hline \multicolumn{2}{|l|}{ Diaphanosoma spinulosum Herbst, 1967} \\
\hline \multicolumn{2}{|c|}{ Copepoda } \\
\hline \multicolumn{2}{|c|}{ CYCLOPYDAE } \\
\hline Thermocyclops decipiens (Kiefer, 1929) & T. minutus (Lowndes, 1934) \\
\hline
\end{tabular}

There was a significant difference (Kruskal-Wallis test $p<0.05)$ in mean species richness between hydrological periods for testate amoebae, cladocerans and rotifers.

Regarding the zooplankton abundance, the highest value (878.47 ind $\mathrm{m}^{-3}$ ) was recorded during the flood period, followed by rising $\left(633.68\right.$ ind. $\left.\mathrm{m}^{-3}\right)$, dry $\left(595\right.$ ind. $\left.\mathrm{m}^{-3}\right)$ and low (473.61 ind. $\mathrm{m}^{-3}$ ) periods (Table 3). Testate amoebae showed greater abundance during the flood period $\left(767.71\right.$ ind. $\left.\mathrm{m}^{-3}\right)$, rotifers during the dry period (308.61 ind $\mathrm{m}^{-3}$ ), cladocerans during the rising period $\left(40.63\right.$ ind $\left.\mathrm{m}^{-3}\right)$ and copepods during the flood period (35.83 ind. $\mathrm{m}^{-3}$ ) (Figure 2c, Table 3 ).

The variation in the mean values of abundance was mainly related to the large contribution of testate amoebae and rotifers (Figure 2d). Testate amoebae was the most abundant group in the study, representing $71.5 \%$ of the zooplankton abundance, followed by rotifers $(22 \%)$, whereas microcrustaceans were the least abundant in the community (3.5\% copepods and $3 \%$ cladocerans). Young stages (nauplii and copepodids) were the main contributors to the abundance of copepods. There was a significant difference (Kruskal-Wallis test $p<0.05$ ) in the mean abundance of all zooplankton groups between hydrological periods.

The cluster analysis (Bray-Curtis coefficient) applied to hydrological periods separated the dry period from the others due to a higher contribution of Filinia opoliensis (Zacharias, 1898) in the community during this period. The remaining periods (low, rising and flood) showed similarity values around $50 \%$ and were grouped separately with high similarity (Figure 3a).

The CCA indicated a significant correlation $(p<0.05)$ between the environmental variables and the abundance of zooplankton groups. The axis 1 of CCA explained $11.7 \%$ of the data variability and the axis 2 explained $7.3 \%$, totalling $19 \%$ of the variability. In general, the analysis shows a clear separation of the dry and rising periods from the other hydrological periods. Most species of testate amoebae were grouped in the low and flood periods, positively correlated with the water velocity, electrical conductivity, temperature, turbidity, chlorophyll- $a$ and $\mathrm{pH}$; however, in the flood, they were dispersed and positively correlated with dissolved oxygen. Rotifers were concentrated in the dry period, negatively correlated to the environmental variables, and dispersed in the other periods. Among microcrustaceans, cladocerans were concentrated mainly in the rising period, positively correlated with dissolved oxygen, and the copepods (including nauplii and copepodids in CCA) in the low and flood periods, positively correlated with the water velocity, electrical conductivity, temperature, turbidity, chlorophyll- $a$ and $\mathrm{pH}$ (Figure $3 \mathrm{~b}$ ).

\section{Discussion}

This study showed that the region of the Upper Parnaíba River has a well-marked seasonal variation given the differences in environmental variables, and the hydrological regime is the main driver of the physical, chemical and biological dynamics of the Upper Parnaíba River. The increase in the river's level was positively associated with higher values of environmental variables, especially chlorophyll- $a$, water velocity and turbidity (mainly from suspended sediment).

Among different zooplankton groups, the testate amoebae were the most abundant and the most species-rich group. The families with the highest number of species (Difflugiidae and Arcellidae) have been identified as prevalent in several studies in various aquatic habitats 
Table 3. Mean abundance ( \pm SE) of Testate amoebae, Rotifera, Cladocera and Copepoda during low, dry, rising and flood periods in the Parnaíba River, Northeastern Brazil.

\begin{tabular}{|c|c|c|c|c|}
\hline \multicolumn{5}{|c|}{ Parnaíba River } \\
\hline Zooplankton & Low & Dry & Rising & Flood \\
\hline Testate amoebae & $341.11 \pm 54.1$ & $264.17 \pm 24.65$ & $464.24 \pm 113.37$ & $767.71 \pm 93.31$ \\
\hline Rotifera & $86.11 \pm 15.96$ & $308.61 \pm 56.41$ & $104.51 \pm 14.15$ & $77.78 \pm 16.33$ \\
\hline Cladocera & $10.56 \pm 3.04$ & $21.94 \pm 9.47$ & $40.63 \pm 15.32$ & $1.74 \pm 0.61$ \\
\hline Copepoda & $35.83 \pm 8.19$ & $0.28 \pm 0.28$ & $24.31 \pm 5.1$ & $31.25 \pm 13.06$ \\
\hline Total & $473.61 \pm 47.01$ & $595 \pm 59.7$ & $633.68 \pm 114.53$ & $878.47 \pm 90.99$ \\
\hline
\end{tabular}
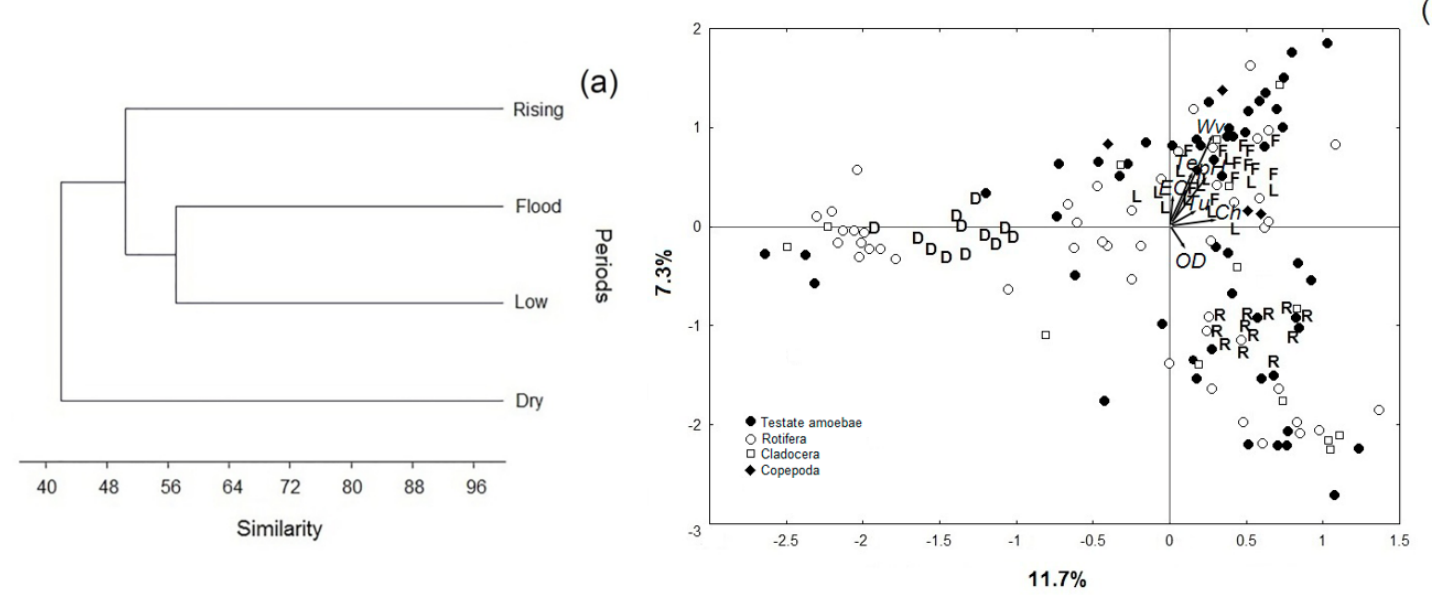

(b)

Figure 3. (a) Dendrogram of cluster analysis: the Bray-Curtis similarity coefficient per hydrological period (low, dry, rising and flood) of the Parnaíba River (Northeastern Brazil) and (b) canonical correspondence analysis (CCA) of environmental variables and zooplankton species abundance. Code: $\mathrm{L}=$ Low; $\mathrm{D}=$ Dry; $\mathrm{R}=$ Rising; $\mathrm{F}=$ Flood; Wv $=$ Water velocity $(\mathrm{m} / \mathrm{s})$; $\mathrm{EC}=$ Electrical conductivity $\left(\mu \mathrm{S} / \mathrm{cm}^{-1}\right) ; \mathrm{Te}=$ Temperature $\left({ }^{\circ} \mathrm{C}\right) ; \mathrm{Tu}=$ Turbidity $(\mathrm{NTU}) ; \mathrm{DO}=$ Dissolved oxygen $\left(\mathrm{mg} / \mathrm{L}^{-1}\right) ;$ $\mathrm{Ch}=$ Chlorophyll- $a\left(\mu \mathrm{g} / \mathrm{L}^{-1}\right)$.

(Velho et al., 2004; Alves et al., 2012; Lansac-Tôha et al., 2009; 2014; Arrieira et al., 2015).

The family Arcellidae, expressive in plankton, usually has small species, of low density and with shells made of endogenous materials secreted by the amoeba, which allows the occupation of the planktonic habitat (Lansac-Tôha et al., 2014). The family Difflugiidae presents species in plankton with the same type of morphology, i.e. spherical shells. This morphological type, along with the types of shells of most of Arcellidae species (hemispherical), is commonly found in plankton (Lansac-Tôha et al., 2014). However, these authors also identified elongated and flattened shapes, which were also observed in plankton in this study, and these species are identified as typical of aquatic macrophytes in the littoral region and sediment.

Among the rotifers, Brachionidae is one of the most important taxa of freshwater zooplankton, whose species usually have planktonic habits, while Lecanidae is related to the benthos and periphyton, especially in sites rich in vegetation, occurring occasionally in the plankton (Almeida et al., 2009). The dominance of these two families is probably due to the great plasticity of the organisms of these families in relation to limnological conditions and food available. The species of these families are usually predominant in tropical rivers and lakes (e.g., Bonecker et al., 2009; Lansac-Tôha et al., 2009; Lucena et al., 2015).

Among the cladocerans, the predominance of Chydoridae is common for river environments, although this type of environment is considered less favourable for the establishment of this group due to predation by fish and high water flow (Viroux, 2002), which suggests that life in lotic environments is related to some specialisation and adaptation to turbulence, which are not evident in cladocerans.

Copepods were represented only by Cyclopidae species, which is related to the ability of this group to inhabit different environments and compartments (littoral, pelagic and benthic zones), unlike the calanoid group, whose species are characteristic of lentic environments (Perbiche-Neves et al., 2012). Most individuals found in the sampled sites were young stages (nauplii and copepodids). Adult copepods have few records in rivers: the young forms are more numerous (Paggi, 1984). This predominance of young stages of copepods in the zooplankton community 
was also reported by other authors (e.g., Nogueira et al., 2008; Almeida et al., 2009; Lansac-Tôha et al., 2009) and is frequently linked to high mortality rates of adult forms, which are more susceptible to predation by planktivorous fish (Paranhos et al., 2013).

Ecological studies on the zooplanktonic fauna in the Parnaíba River channel are lacking. The few existing studies are mostly restricted to the fauna of rotifers and microcrustaceans (e.g., Medeiros et al., 2011; Lucena et al., 2015). Studies on testate protozoa are non-existent in the region, precluding comparisons.

The cluster analysis (Bray-Curtis coefficient) distinguished the dry period from the others. This is explained by the greater difference found in the total species abundance, evidenced by a greater contribution of $F$. opoliensis to the zooplankton community in the dry period. Suggesting that this species found better conditions in which to settle and colonise the environment in this period. The other periods presented high similarity, which did not allow a clear view of the predominance of any particular taxon.

The CCA showed that testate amoebae were grouped in periods with higher water levels. The data suggest that the increase in the abundance of these protists is mainly due to the higher water velocity and turbidity in the Parnaíba River basin. Although testate amoebae are mainly associated with sediment and littoral vegetation, they are considered common in plankton, transported to the water column with the suspension of sediment caused by water turbulence (Velho et al., 2004; Alves et al., 2012; Lansac-Tôha et al., 2009, 2014; Arrieira et al., 2015).

The abundance of rotifer species was concentrated in the dry period; the lower water velocity may have favoured the colonisation of this group. Thorp and Mantovani (2005) and Baranyi et al. (2002) reported that the abundances of rotifers were significantly reduced during periods of higher water flow; only in periods of lower water flow the appearance of sandbar islands promoted hydrological retention areas favouring an increase in the abundance of these organisms.

The low correlation of microcrustaceans with environmental variables may be related to the hydrological characteristics of the region, which do not provide ideal sites for development of these organisms, mainly due to the influence of the water velocity. Organisms with higher swimming capacities can develop in these environments, as slower organisms are transported by the current. Thorp and Mantovani (2005) found similar results in rivers of the semi-arid in large plains in the USA, suggesting that the water velocity and the suspension of high loads of sediment act directly in reducing the abundance and number of microcrustacean species, dispersing them and preventing successful colonisation.

There is widespread consensus that potamoplankton is regulated mainly by abiotic factors (Baranyi et al., 2002). According to Thorp and Mantovani (2005), especially the turbidity and the hydrological retention (influenced by the flow velocity and low velocity areas - slackwaters) are important for potamoplankton.
In other Brazilian rivers, it is recognised that the flow and lateral connectivity of the river with the floodplain wetlands are the main structuring factors for the zooplankton biodiversity (e.g., Bozelli and Huszar, 2003; Casanova and Henry, 2004; Lansac-Tôha et al., 2009). Nevertheless, due to the absence of floodplain wetlands in semi-arid rivers, this factor is not important. The Brazilian semi-arid waterways are geomorphologically characterised as courses with no meanders and no floodplains, with floods restricted to the main river channel (Maltchik and Medeiros, 2006). On the other hand, during the floods, longitudinal connections between isolated water bodies seems to be an important factor in the spread and maintenance of biodiversity in these systems (Medeiros and Maltchik, 2001; Medeiros et al., 2011; Lucena et al., 2015).

The predicted proposals that could explain the increase in zooplanktonic species richness and abundance during the flood and dry periods, respectively, were rejected. Therefore, our results suggest that the Parnaíba River has characteristics common to other rivers found in the Brazilian semi-arid region, including well-marked seasonality, where hydrological periods reflect directly on the river flow velocity, pointed out as the main factor that drives the zooplankton community structure, transporting the organisms from the sediment and aquatic macrophytes of the littoral region to the plankton. This study also highlighted the importance of the Parnaíba River and its seasonal variation for biodiversity conservation in the Brazilian semi-arid region.

\section{Acknowledgements}

The authors are grateful to Dr. Luiz Felipe Machado Velho and Dr. Geziele Mucio Alves for suggestions. The Coordenação de Aperfeiçoamento de Pessoal de Nível Superior (CAPES) for the doctoral scholarship to the first author. We thank Grupo de Pesquisas em Recursos Pesqueiros e Limnologia (GERPEL) of the Universidade Estadual do Oeste do Paraná (UNIOESTE) for providing logistical support for collecting and analysing materials.

\section{References}

ALMEIDA, V.L.S., DANTAS, E.W., MELO-JÚNIOR, M., BITTENCOURT-OLIVEIRA, M.C. and MOURA, A.N., 2009. Zooplanktonic community of six reservoirs in Northeast Brazil. Brazilian Journal of Biology = Revista Brasileira de Biologia, vol. 69 , no. 1 , pp. 57-65. http://dx.doi.org/10.1590/S151969842009000100007. PMid:19347146.

ALVES, G.M., VELHO, L.F.M., COSTA, D.M. and LANSACTÔHA, F.A., 2012. Size structure of testate amoebae (Arcellinida and Euglyphida) in different habitats from a lake in the upper Paraná River floodplain. European Journal of Protistology, vol. 48, no. 3, pp. 169-177. http://dx.doi.org/10.1016/j.ejop.2011.10.004. PMid:22261279.

ARRIEIRA, R.L., ALVES, G.M., SCHWIND, L.T.F. and LANSACTÔHA, F.A., 2015. Local factors affecting the testate amoebae community (Protozoa: Arcellinida; Euglyphida) in a neotropical floodplain. Journal of Limnology, vol. 74, no. 3, pp. 444-452. 
BARANYI, C., HEIN, T., HOLAREK, C., KECKEIS, S. and SCHIEMER, S., 2002. Zooplankton biomass and community structure in a Danube River floodplain system: effects of hydrology. Freshwater Biology, vol. 47, no. 3, pp. 473-482. http://dx.doi. org/10.1046/j.1365-2427.2002.00822.x.

BONECKER, C.C., AOYAGUI, A.S.M. and SANTOS, R.M., 2009. The impact of impoundment on the rotifer communities in two tropical floodplain environments: interannual pulse variations. Brazilian Journal of Biology = Revista Brasileira de Biologia, vol. 69, no. 2, (suppl.), pp. 529-537. http://dx.doi.org/10.1590/ S1519-69842009000300008. PMid:19738960.

BOZELLI, R.L. and HUSZAR, V.L.M., 2003. Comunidades fito e zooplanctônicas continentais em tempo de avaliação. Limnotemas, vol. 3, pp. 1-32.

BRASIL. Ministério do Meio Ambiente. Secretaria de Recursos Hídricos, 2006. Caderno da região hidrográfica do Parnaíba. Brasília: MMA. 240 p.

CASANOVA, S.M. and HENRY, R., 2004. Longitudinal distribution of Copepoda populations in the transition zone of Paranapanema river and Jurumirim reservoir (São Paulo, Brazil) and interchange with two lateral lakes. Brazilian Journal of Biology $=$ Revista Brasileira de Biologia, vol. 64, no. 1, pp. 11-26. http://dx.doi. org/10.1590/S1519-69842004000100003. PMid:15195360.

COMPANHIA DE DESENVOLVIMENTO DOS VALES DO SÃO FRANCISCO E DO PARNAÍBA - CODEVASF, 2010 [viewed 26 November 2015]. Rio Parnaiba: aspectos geográficos e recursos naturais [online]. Brasília: CODEVASF. Available from: http://www.codevasf.gov.br/

ELMOOR-LOUREIRO, M.A.L., 1997. Manual de identificação de cladóceros límnicos do Brasil. Brasília: Universa. 155 p.

EMPRESA DE PESQUISA ENERGÉTICA-EPE, 2005 [viewed 26 November 2015]. Termo de referência da Avaliação Ambiental Integrada - AAI dos aproveitamentos hidrelétricos da bacia do rio Parnaiba [online]. Available from: http://www.epe.gov.br

ESKINAZI-SANT'ANNA, E.M., MENEZES, R., COSTA, I.S., PANOSSO, R.F., ARAÚJO, M.F. and ATTAYDE, J.L., 2007. Composição da comunidade zooplanctônica em reservatórios eutróficos do semi-árido do Rio Grande do Norte. Oecologia Brasiliensis, vol. 11, no. 3, pp. 410-421. http://dx.doi.org/10.4257/ oeco.2007.1103.10.

GOLTERMAN, H.L., CLYMO, R.S. and OHMSTAD, M.A.M., 1978. Methods for physical and chemical analysis of fresh waters. Oxford: Blackwell Scientific Publications. 213 p.

KOSTE, W., 1978. Rotatoria die Rädertiere Mitteleuropas begründet von Max Voight: Monogononta. Berlin: Gebrüder Borntraeger. $673 \mathrm{p}$.

LANSAC-TÔHA, F.A., VELHO, L.F.M., HIGUTI, J. and TAKAHASHI, E.M., 2002. Cyclopidae (Crustacea, Copepoda) from the Upper Paraná River Floodplain, Brazil. Brazilian Journal of Biology = Revista Brasileira de Biologia, vol. 62, no. 1, pp. 125-133. http://dx.doi.org/10.1590/S1519-69842002000100015. PMid:12185912.

LANSAC-TÔHA, F.A., BONECKER, C.C., VELHO, L.F.M., SIMÕES, N.R., DIAS, J.D., ALVES, G.M. and TAKAHASHI, E.M., 2009. Biodiversity of zooplankton communities in the Upper Paraná River floodplain: interannual variation from longterm studies. Brazilian Journal of Biology $=$ Revista Brasileira de Biologia, vol. 69, no. 2, (suppl.), pp. 539-549. http://dx.doi. org/10.1590/S1519-69842009000300009. PMid:19738961.
LANSAC-TÔHA, F.A., VELHO, L.F.M., SIMÕES, N.R., COSTA, D.M. and ALVES, G.M., 2014. Structure of the testate Amoebae community in different habitats in a Neotropical Floodplain. Brazilian Journal of Biology $=$ Revista Brasileira de Biologia, vol. 74, no. 1, pp. 181-190. http://dx.doi.org/10.1590/15196984.24912. PMid:25055100.

LUCENA, L.C.A., MELO, T.X. and MEDEIROS, E.S.F., 2015. Zooplankton community of Parnaíba River, Northeastern Brazil. Acta Limnologica Brasiliensia, vol. 27, no. 1, pp. 118-129. http:// dx.doi.org/10.1590/S2179-975X3214.

MALTCHIK, L. and MEDEIROS, E.S.F., 2006. Conservation importance of semi-arid streams in north-eastern Brazil: implications of hydrological disturbance and species diversity. Aquatic Conservation, vol. 16, no. 7, pp. 665-677. http://dx.doi. org/10.1002/aqc. 805 .

MANLY, B.J.F., 2008. Métodos estatísticos multivariados: uma introdução. Porto Alegre: Bookmann. $230 \mathrm{p}$

MATSUMURA-TUNDISI, T., 1986. Latitudinal distribution of Calanoida copepods in freshwater aquatic systems of Brazil. Brazilian Journal of Biology = Revista Brasileira de Biologia, vol. 46 , no. 3, pp. 527-553.

MCCUNE, B. and MEFFORD, M.J., 1997. PC-ORD: multivariate analysis of ecological data, version 3.0. Oregon: MjM Software Design.

MEDEIROS, E.S.F. and MALTCHIK, L., 2001. Fish assemblage stability in an intermittently flowing stream from the Brazilian semiarid region. Austral Ecology, vol. 26, no. 2, pp. 156-164. http://dx.doi.org/10.1046/j.1442-9993.2001.01099.x.

MEDEIROS, E.S.F., NOIA, N.P., ANTUNES, L.C. and MELO, T.X., 2011. Zooplankton composition in aquatic systems of semi-arid Brazil: spatial variation and implications of water management. Pan-American Journal of Aquatic Sciences, vol. 9, no. 4, pp. 290-232.

NOGUEIRA, M.G., OLIVEIRA, P.C.R. and BRITTO, Y.T., 2008. Zooplankton assemblages (Copepoda and Cladocera) in a cascade of reservoirs of a large tropical river (SE Brazil). Limnetica, vol. 27, no. 1, pp. 151-170.

PAGGI, S.J., 1984. Estudios limnológicos en una sección transversal del tramo medio del río Paraná. X: distribución estacional del zooplancton. Revista de la Asociacion de Ciencias Naturales del Litoral, vol. 15, no. 2, pp. 135-155.

PARANHOS, J.D.N., ALMEIDA, V.L.S., SILVA-FILHO, J.P., PARANAGUÁ, M.N., MELO-JÚNIOR, M. and NEUMANNLEITÃO, S., 2013. The zooplankton biodiversity of some freshwater enviroments in Parnaíba basin (Piauí, Northeastern Brazil). Brazilian Journal of Biology = Revista Brasileira de Biologia, vol. 73, no. 1, pp. 125-134. http://dx.doi.org/10.1590/ S1519-69842013000100014. PMid:23644795.

PEEL, M.C., FINLAYSON, B.L. and MCMAHON, T.A., 2007. Updated world map of the Koppen-Geiger climate classification. Hydrology and Earth System Sciences, vol. 11, no. 5, pp. 16331644. http://dx.doi.org/10.5194/hess-11-1633-2007.

PERBICHE-NEVES, G., SERAFIM-JÚNIOR, M., PORTINHO, J.L., SHIMABUKURO, E.M., GHIDINI, A.R. and BRITO, L., 2012. Effect of atypical rainfall on lotic zooplankton: comparing downstream of a reservoir and tributaries with free stretches. Tropical Ecology, vol. 53, no. 2, pp. 149-162.

REID, J.W., 1985. Chave de identificação e lista de referências bibliográficas para as espécies continentais sul americanas de 
vida livre da ordem Cyclopoida (Crustacea, Copepoda). Boletim de Zoologia, vol. 9, pp. 17-143.

ROSA, R.S., MENEZES, N.A., BRITSKI, H.A., COSTA, W.J.E.M. and GROTH, F., 2003. Diversidade, padrões de distribuição e conservação dos peixes da Caatinga. In: I.R. LEAL, J.M.C. SILVA and M. TABARELLI, eds. Ecologia e conservação da caatinga. Recife: Edufpe, pp. 135-181.

SEGERS, H., 1995. Rotifera: the Lecanidae (Monogonta): guides to the identification of the micro invertebrates of the continental water of the world. Netherlands: The Hague. 226 p.

THORP, J.H. and MANTOVANI, S., 2005. Zooplankton of turbid and hydrologically dynamic prairie rivers. Freshwater Biology, vol. 50, no. 9, pp. 1474-1491. http://dx.doi.org/10.1111/j.13652427.2005.01422.x

VALENTIN, J.L., 2000. Ecologia numérica: uma introdução à análise multivariada de dados ecológicos. Rio de Janeiro: Interciência. $117 \mathrm{p}$.

VELHO, L.F.M. and LANSAC-TÔHA, F.A., 1996. Testate amoebae (Rhizopodea-Sarcodina) from zooplankton of the high Paraná river floodplain, state of Mato Grosso do Sul, Brazil: II. Family
Difflugiidae. Studies on Neotropical Fauna and Environment, vol. 31, no. 3, pp. 174-192.

VELHO, L.F.M., LANSAC-TÔHA, F.A. and SERAFIM-JÚNIOR, M., 1996. Testate amoebae (Rhizopodea-Sarcodina) from zooplankton of the high Paraná river floodplain, State of Mato Grosso do Sul, Brazil: I. Families Arcellidae and Centropyxidae. Studies on Neotropical Fauna and Environment, vol. 3, no. 1, pp. 135-150.

VELHO, L.F.M., BINI, L.M. and LANSAC-TÔHA, F.A., 2004. Testate amoeba (Rhizopoda) diversity in plankton of the Upper Paraná River Floodplain, Brazil. Hydrobiologia, vol. 523, no. 3, pp. 103-111. http://dx.doi.org/10.1023/B:HYDR.0000033098.46753.9f.

VIROUX, L., 2002. Seasonal and longitudinal aspects of microcrustacean (Cladocera: Copepoda) dynamics in lowland river. Journal of Plankton Research, vol. 24, no. 4, pp. 281-292. http://dx.doi.org/10.1093/plankt/24.4.281.

VUCETICH, M.C., 1973. Estudio de tecamebianos argentinos, en especial los del dominio pampasico. Revista del Museo de La Plata, vol. 118, no. 11, pp. 287-322.

ZAR, J.H., 1999. Biostatistical analysis. New Jersey: Prentice Hall. 663 p. 